\title{
Review
}

\section{Origin and Chemical Variation of Brazilian Propolis}

\author{
Antonio Salatino', Érica Weinstein Teixeira ${ }^{2}$, Giuseppina Negri ${ }^{1}$ and Dejair Message ${ }^{3}$ \\ ${ }^{1}$ Department of Botany, Institute of Biosciences, University of São Paulo, São Paulo, SP, ${ }^{2}$ APTA (Agência \\ Paulista de Tecnologia dos Agronegócios)/SAA-SP, Pindamonhangaba, SP and ${ }^{3}$ Viçosa Federal University, \\ Department of Animal Biology, Viçosa, MG, Brazil
}

\begin{abstract}
Propolis is a hive product containing chiefly beeswax and plant-derived substances such as resin and volatile compounds. Propolis has been used as an antiseptic and wound healer since ancient times and interest for the product has increased recently. Probably few plant species contribute as major resin sources. Green propolis derives mainly from vegetative apices of Baccharis dracunculifolia (alecrim plants). However, wide variation detected in the chemical composition suggests contributions from alternative resin plant sources. Predominant components of the resin of green propolis are cinnamic acids, chiefly compounds bearing prenyl groups. Terpenoid compounds, such as sesqui, di and pentacyclic triterpenoids, have been detected in many, but not all, samples investigated. Propolis research has uncovered potentialities of substances previously isolated from plants and has detected constituents of plant origin that would hardly be known otherwise.
\end{abstract}

Keywords: africanized Apis mellifera - Baccharis dracunculifolia - flavonoids - prenylated phenylpropanoids - propolis - terpenoids

\section{Introduction}

Propolis is a complex resinous bee product with a physical appearance that varies widely, depending on many factors. The color may be cream, yellow, green, light or dark brown. Some samples have a friable, hard texture, while other samples may be elastic and gummy. The word propolis is of Greek origin, stemming from pro, in defense of, and polis, city. It thus implies a product involved in the defense of the bee community. Bees use propolis for diverse purposes, among them to seal openings in the hive. In addition to avoiding the entrance of intruders, this contributes to maintaining the hive inner temperature at around $35^{\circ} \mathrm{C}$. The walls of the comb hexagonal cells contain a mixture of beeswax and propolis. It is believed that propolis not only hardens the cell walls but also contributes to the attainment of an internal aseptic environment (1). The entrance to the hive is also lined internally with propolis. Evidence that leaves no doubt as to the anti-microbial properties of propolis comes from another use of the product in the hive: bees cover the carcasses of intruders that were killed and are too heavy to be thrown off the

For reprints and all correspondence: Antonio Salatino, University of São Paulo, Institute of Biosciences, Department of Botany, C. Postal. 11461, 05422-970, São Paulo, SP, Brazil. Tel.: +55 113091 7532;

Fax: +55 113091 7416; E-mail: asalatin@ib.usp.br hive (e.g., small snakes) with propolis. The process comes close to an embalming effect, because the dead bodies dry out without undergoing putrefaction (1). This is obviously important to protect the hive from a widespread bacterial infection. Recognition of the antiseptic efficacy of propolis is ancient. Aristotle recommended the use of propolis to treat abscesses and wounds. Roman soldiers carried propolis as an emergency medicine for war wounds. A medicine containing vaseline and propolis (propolisin vasogen) was used for wound treatment (2) during the Boer war.

Propolis composition is extremely complex. The main constituents are beeswax, resin and volatiles. The insects secrete beeswax, while the latter two constituents are obtained from plants. But contrary to the well-known habit of visiting flowers for collection of nectar and pollen, bees usually take plant material for propolis from plant secretions or by cutting fragments of vegetative tissues (but see below comments about Venezuelan and Cuban propolis). The biological activity of propolis is assigned to these plant-derived substances. Hence, although propolis is obviously an animal product, a considerable proportion of its components, chiefly those upon which rest its biological activity, are plant derived. The resin contains most of the compounds found in alcohol extracts consumed by people from many countries as food complements or alternative

(C) The Author (2005). Published by Oxford University Press. All rights reserved.

The online version of this article has been published under an open access model. Users are entitled to use, reproduce, disseminate, or display the open access version of this article for non-commercial purposes provided that: the original authorship is properly and fully attributed; the Journal and Oxford University Press are attributed as the original place of publication with the correct citation details given; if an article is subsequently reproduced or disseminated not in its entirety but only in part or as a derivative work this must be clearly indicated. For commercial re-use, please contact journals.permissions@ oupjournals.org 
medicine. Propolis contains other constituents, such as pollen and amino acids (3,4). In their reviews, Marcucci (5) and Bankova et al. (6) registered over 300 known substances in propolis. Reports in the last 10 years have added a great deal of other substances [e.g. Banskota et al. (7)].

In modern times, propolis started gaining appreciation as a means for the treatment of health problems in the 1950s and 1960s in the former Soviet Union and countries of Eastern Europe, such as Bulgaria, Czechoslovakia and Poland. Matsuno (2) mentions the use of propolis in these countries in cases of chronic medium and external otitis, pharyngitis, chronic rhinitis, amygdalitis and bronchial asthma, among other ailments, with satisfactory results. In Western European countries, in North and South America and in Japan, propolis did not acquire popularity until the 1980s. In the latter country, the first important announcement of propolis as a promising possibility in pharmacology occurred in 1985 (30th International Apiculture Congress, Nagoya). Up to that time, propolis was regarded by beekeepers as an unwanted hive by-product, since it had no market value and its production meant a decline in the amounts of honey obtained. Starting with a gradual rise in interest from people from several countries in the mid 1980s, propolis ended up as an important product in complementary and alternative medicine. Japan is the leading importer of propolis, with a manifest preference for propolis from Brazil.

Presently, many beekeepers in Brazil have, in propolis, their major product, and develop means to maximize its production. One of them is to leave longitudinal slits on both sides of the wooden box that shelters the bee colony. This method relies on the bee's behavior of depositing propolis seals on all openings they detect in the hive (Fig. 1).

A great enthusiasm characterizes present-day propolis research, driven by positive results in pharmacological tests, dealing not only with anti-microbial activity, the first [Lavie (8)] and as yet the most investigated effect in propolis research, but also with a wide diversity of effects, including immune activation and cytotoxicity (9).

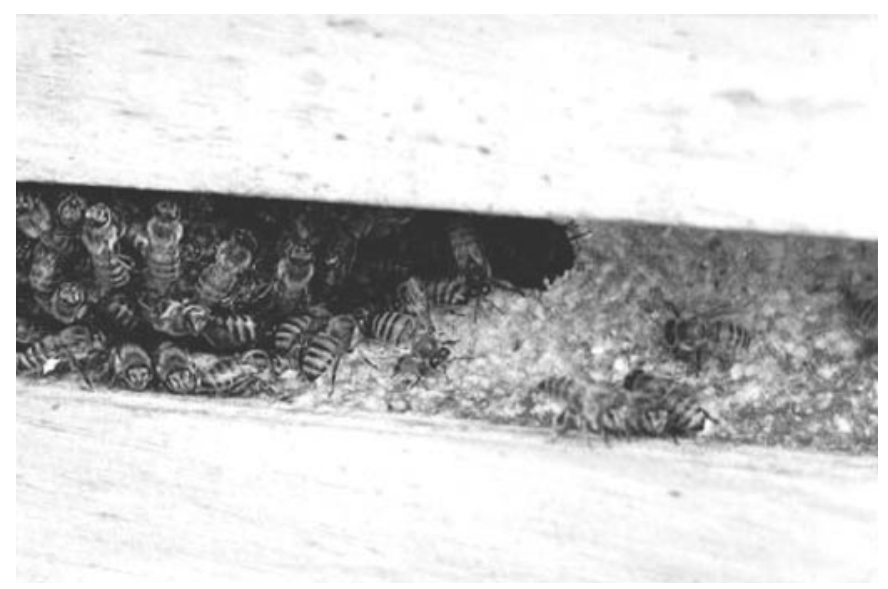

Figure 1. A wooden box housing a honeybee hive with a lateral slit, which enhances propolis production. Propolis was removed from the left side and bees are working to seal the resultant opening with new propolis deposits.
Besides pharmacological activity, an important point in propolis research refers to its botanical origin and the consequent variation in chemical composition when samples from different locations, and even from the same locality, are compared. Propolis samples produced in Europe and South America share anti-microbial, anti-viral, wound-healing, immune- stimulating, anti-inflammatory and anesthetic activities. However, similar as these samples might be in their biological activities, they are quite different chemically (10), because different plants in Europe and South America provide resin for propolis production in the two continents. In typical European propolis the major pharmacologically active constituents have long been identified as flavonoids, the most common and abundant being galangin (11). It is now well established that such a chemical profile is a consequence of the fact that in Europe bees collect propolis resin mainly from vegetative poplar (Populus nigra, Salicaceae) buds (12). In the tropics, poplars are seldom cultivated, so alternative plants are sources of propolis resin. For example, the flowers of Clusia minor in Venezuela (13) and of Clusia rosea in Cuba (14) produce resin, which bees collect for propolis production. In both cases, flavonoids are minor propolis constituents, the major compounds being polyprenylated benzophenones.

The present paper intends to put forward general comments about the plant origin of green propolis and its varying chemical composition.

\section{Origin of Green Propolis}

Among the propolis types produced in Brazil, green propolis has gained preference in the world propolis market. Typical green propolis is hard and friable, easily made into powder by mechanical milling. It exhales a pleasant resinous odor and the color ranges from greenish-yellow to deep green. Lack of records on propolis characteristics means that a comparison between the contemporary product and samples produced before 1960 in Brazil cannot be made. Such data could reveal possible influences of the genetic change that took place after the accidental escape of African Apis mellifera scutellata queen bees (15) from a laboratory in the State of São Paulo (southeast Brazil). All honeybees in Brazil are now africanized and presumably more productive than European bees with regard to propolis. The degree of introgression of the African genes varies according to geography, probably because of a gradual loss of European genes due to a better fitness of the African gene pool to the neotropical environment (16). Chemical affinities based on comb and propolis waxes in Brazil (17) probably reflect genetic differences linked to a higher or lower incidence of the African genes.

Suggestions have been made that probable sources of Brazilian propolis are Araucaria heterophylla, Clusia major, Clusia minor and species of Baccharis (7). Other possible sources of Brazilian propolis that have been suggested are Araucaria angustifolia, Baccharis dracunculifolia and Eucalyptus citriodora (18). Chemical evidence has suggested that some Baccharis species are resin sources for propolis from Botucatu (São Paulo State, southeast Brazil) (6). 
Analyses of pollen and plant structures in propolis samples from cerrado (a savanna Brazilian ecosystem in central and southeastern Brazil) suggest that bees visit species of Baccharis, Vernonia, Diclenia, Hyptis, Myrcia, Schinus and Weinmania (19) for resin collection. While remains of vegetative structures may be given credit as consistent evidence for propolis origin, pollen analysis is dangerously misleading, because it is impossible to know with certainty whether a detected pollen is the result of a visit aimed at collecting resin or just a contamination of material obtained by bees for other purposes. Secretory hairs belonging to Baccharis dracunculifolia (called alecrim in some parts of Brazil) have been found in high quantities in both dry and rainy seasons (20). Alecrim is used in traditional medicine and corresponds to a dioecious shrubby member of the Asteraceae, widely distributed in open field ecosystems of southeast and south Brazil, spreading into Uruguay, Argentina, Paraguay and Bolivia (21). Identical prenylated cinnamic acids have been found in its leaves and in Brazilian propolis (22). A similar composition has also been observed between alecrim material and propolis from the state of São Paulo. Direct evidence for such a relationship has been provided (22), through observations of bee behavior and chemical analyses of alecrim leaves and propolis.

An attempt to classify propolis produced in Brazil according to botanical origin and chemical composition (23) recognized 12 types. Five of them correspond to southern, one to southeastern and six to northeastern regions of the country. It was suggested that Hyptis divaricata is the resin source of northeastern propolis, Baccharis dracunculifolia of southeastern propolis and poplar (Populus nigra) of southern propolis. This study by Park et al. (23) is indicative that just stating that a certain sample corresponds to 'Brazilian propolis' hardly means anything indicative of physical, chemical and biological characteristics, because a wide diversity of propolis types exist in a country as huge as Brazil, housing a wide plant diversity and a complex honeybee genetic variation. Most studies on 'Brazilian propolis' published in recent years have, in fact, dealt with the southeastern type, classified as 'group 12' (green propolis), such selectivity by propolis researchers reflecting the above mentioned international market preference. Given the widespread occurrence of B.dracunculifolia not only in the southeast but also in the south of Brazil, claims that the origin of the southern propolis are poplar trees (23) may be an oversimplification of the real range of propolis types in that region. For example, chemical evidence led Bankova et al. (24) to suggest that Araucaria may be a resin source for samples of propolis from southern Brazil, based on the finding of labdanetype diterpenes in propolis from that region and the fact that natural populations of Araucaria angustifolia characterize Brazilian southern flora; however, those compounds were shown to be present also in leaves of B.dracunculifolia (25).

The characteristic green color of alecrim-propolis is a consequence of its botanical origin, because bees collect young chlorophyll-containing tissues, namely vegetative buds and unexpanded leaves of B.dracunculifolia. Such young leaves contain secretory hairs, probably with volatile and aromatic oils inside, hence the resinous aroma of the typical green propolis. Volatile oils have been studied from Baccharis species $(26,27)$. A volatile oil is obtained from the leaves of B.dracunculifolia and is commercially marketed under the name of vassoura oil (28).

Not so long ago beekeepers and many researchers shared a view that bees in Brazil collected material from practically any abundant plant source in the neighborhood of the hive, be it eucalyptus, pine, sugar cane, cashew nut or orange trees. It was usually said that this or that product was a 'eucalyptus propolis' or 'pine propolis'. Such an idea probably derived from the common observation that bees visit a wide diversity of plants seeking nectar and pollen. The accumulated experimental data on propolis origin have not given support to such assumptions. It seems that certain plants are in fact major providers of propolis resin, while many others do not fit this role. It is, however, premature to conclude that in Brazil a certain plant species is the sole resin source for a certain propolis type. Indeed the probability is higher that, depending on the availability of representatives in the field, plants of a certain species prevail to a higher or lower extent as resin sources, while other species may also contribute (sometimes substantially) material for propolis production. The latter possibility is coherent with observations of more or less strong deviations from an expected chemical profile for a propolis type, a circumstance frequently pervading studies of propolis chemistry.

\section{Chemical Composition}

This is not a full account of what has been done on the chemistry of green propolis, rather it is a general idea of the diversity of classes of secondary metabolites and the extent of variation that has been noted in green propolis composition. Since most analyses carried out with European propolis until the mid 1990s revealed that flavonoids predominated as resin constituents, researchers assumed that a similar picture was apt to prevail regarding Brazilian propolis, especially taking into consideration that such propolis samples were pharmacologically similar to the European counterparts. However, contrary to those expectations, the first detailed chemical analyses revealed quite distinct profiles for samples of Brazilian propolis. Prenylated phenylpropanoids were shown to be very common and abundant constituents in propolis from Brazil, mainly from the southeastern region. For example Banskota et al. (29) identified in a sample of 'Brazilian propolis' pharmacologically active prenylated cinnamic acid-derived compounds, four of them bearing a prenyl group making up a heterocyclic ring that gives rise to chromenes (Fig. 2A). Although no information was given as to the provenance of the propolis sample, investigation carried out in Japan with Brazilian propolis deal practically only with green propolis. Other cinnamic acidderived compounds common in green propolis have one or two prenyl groups not involved with ring formation. Prenylated cinnamic acids turned out to be a salient chemical feature of green propolis. Among the non-chromene prenylated cinnamic acids of green propolis, artepillin C (Fig. 2B) has attracted 

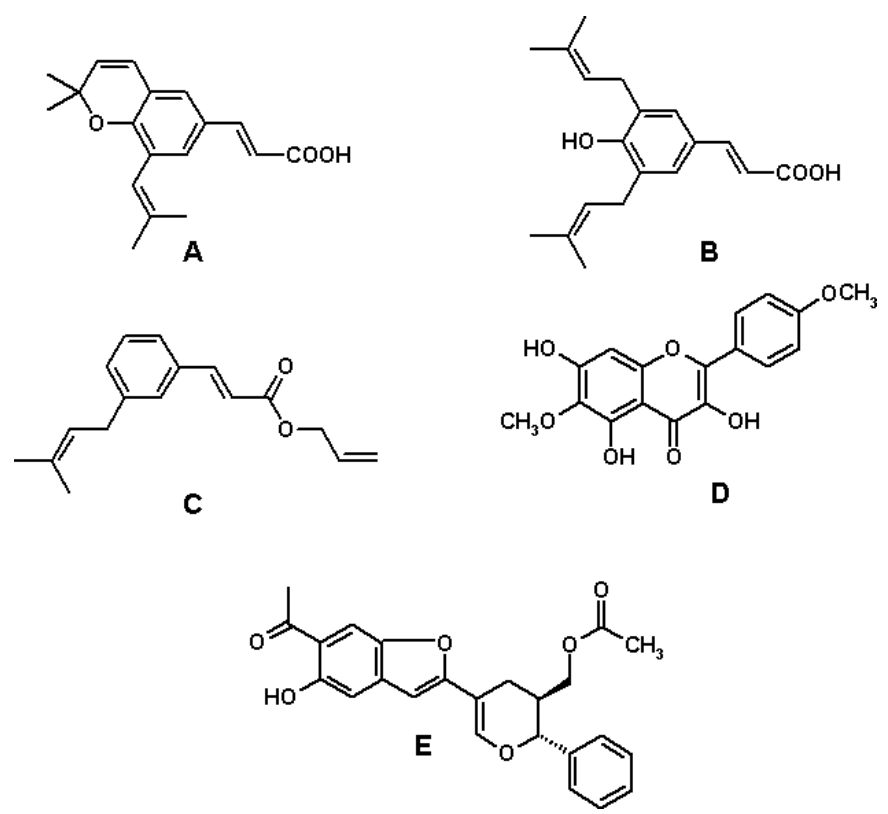

Figure 2. Structures of phenolic compounds isolated from green propolis. (A) 2,2-Dimethyl-8-prenylchromene; (B) 4-hydroxy-3,5-diprenyl cinnamic acid (artepillin C); (C) 3-prenyl cinnamic acid allyl ester; (D) kaempferide; (E) propolis benzofuran A. See text for references.

great attention, not only for its antimicrobial (30) but also for its toxicity to tumor cells (31). Prenylated cinnamic acids may be present as esters, such as 3-prenyl-cinnamic acid allyl ester (32) (Fig. 2C). Despite not being major constituents, flavonoids do occur in green propolis, one frequent example being kaempferide (Fig. 2D), a compound shown to possess antioxidant activities (33). Interesting benzofurans (Fig. 2E), to our knowledge never detected in B.dracunculifolia, were obtained from Brazilian propolis and shown to possess cytotoxic properties (34).

Mono and sesquiterpenes are frequently detected in green propolis, accounting for its characteristic resinous odor and probably contributing to the antimicrobial activity. For example, farnesol (Fig. 3D) has been shown to affect the accumulation and polysaccharide content of Streptococcus mutans biofilms (35). Labdane-type diterpenes, several with hepatoprotective activity (25), such as isocupressic (Fig. 3A) and agathic acid, have been found in green propolis. Clerodane diterpenoids with anticancer activity have been isolated, such as 13-symphyoreticulic acid (36) (Fig. 3B). Non-volatile sesquiterpenes, such as dehydrocostus lactone, a compound shown to inhibit the killing function of cytotoxic T-lymphocytes (37), may also occur in green propolis (38). Triterpenoids, some with wide occurrence in plants, have been found in green propolis (38-40). Two novel esters of long chain fatty acids and the pentacyclic triterpenoid lupeol (procrims a and b, Fig. 3C) have also been obtained from green propolis (41). Notwithstanding botanical origin being a major factor affecting propolis chemistry, other aspects also seem to influence the product composition. Notable differences are often found between propolis samples, not only from distant but also from

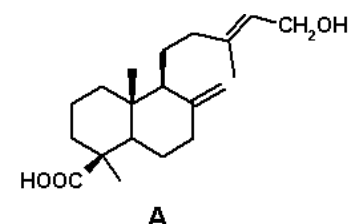

A

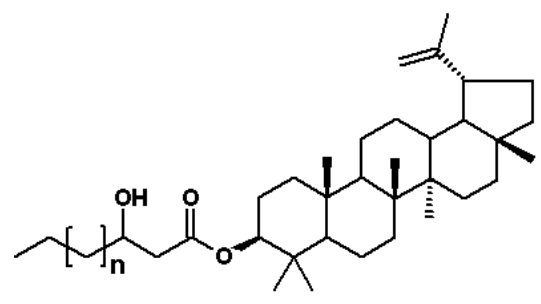

C
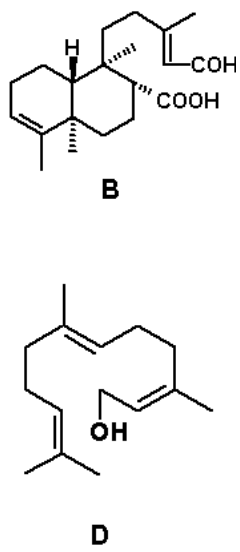

Figure 3. Structures of terpenoids isolated from propolis. (A) Isocupressic acid, a labdane diterpenoid; (B) 13C-symphyoreticulic acid, a clerodane diterpenoid; (C) esters of long chain fatty acids (3-hydroxystearic acid $n=11$, procrim a; 3-hydroxystearic acid $n=13$, procrim b) and a pentacyclic triterpenoid (lupeol); (D) Farnesol a sesquiterpenoid, see text for references.

nearby, or even the same, locations. This holds either for European $(42,43)$ or for green propolis $(32,38,39)$, even restricting the analysis to samples of 'typical' green propolis. For example, 3-prenylcinnamic acid allyl ester (Fig. 2C) was only recently reported to be a major constituent of green propolis (32), despite the considerable number of previous analyses. Among samples of green propolis there seems to be a gradual variation in the proportion of mevalonate-derived substances (terpenoids, including sesqui, di and triterpenoids) and the typical shikimate-derived (phenolics, prenylated or not) compounds. For example, analyses of green propolis have detected pentacyclic triterpenoids in some samples $(38,39)$ but not in others (32). The relative amount of triterpenoids may sometimes be evaluated by the physical appearance of the sample, which loses the hardness and depth of green, turning increasingly cream and pulverulent with increasing levels of triterpenoids and reduction in the amounts of the typical shikimate derivatives. A relatively high content of dehydrocostus lactone (a pharmacologically active sesquiterpenoid $(37,44)]$ was found in a sample from the state of São Paulo, together with 14 pentacyclic triterpenoids, four of them unreported for propolis (39). Bauer-7-en-3-yl acetate (a triterpenoid) was found in this sample in relatively low amounts, but we found it to represent $7 \%$ of the weight of another sample in a region where green propolis predominates (unpublished results). Are such inconsistencies accounted for by behavioral shifts to alternative resin plant sources? Baccharis is a large genus, with many representative species in the Brazilian flora. Species of the genus other than B.dracunculifolia are likely providers of propolis resin, not to mention species of other plant groups, including Clusiaceae, which are known to be predominant resin sources in Venezuela and Cuba, as noted above.

Park et al. (20) verified that very young leaves of B.dracunculifolia had chemical composition similar to the vegetative buds of the same plant, but the composition of successively more expanded leaves showed an increasing 
deviation from the bud pattern. Could this developmental factor account for some of the differences in chemical composition between propolis samples of the same region?

It very likely that phenological differences in plant chemistry may be another important effect accounting for divergences in propolis composition. Another point that may be put forward is the behavioral factors linked to the random location of a different source. It is well known that a bee can sometimes find a suitable source of plant material and then return to the hive, where it performs a 'dance' by means of which their sister laborers are informed about the location of the new source.

Finally, what could be said about genetic factors? How strong is the likelihood that the degree of africanization introgression may affect preference of honeybees for B.dracunculifolia?

\section{Concluding Remarks}

A matter of great concern regarding the production and use of propolis is the variation of its chemical composition, which has motivated proposals for quality chemical control $(45,46)$. It has been claimed that the inconsistency of chemical composition, provided the product houses active antimicrobial substances, is a favorable characteristic, from the point of view that it precludes the development of resistance by microrganisms. Hence, propolis should be viewed more appropriately as a complex natural resource for the control of microorganisms rather than as a source of potent antimicrobials (10). Such a view from the scientific community meets the expectation of a large proportion of the population of many western and oriental countries, who seek alternative, natural (and hence complex) means for nutrition and health care, while placing great distrust in potent and technologically developed pharmaceuticals containing pure compounds. However, propolis has been the subject of research aiming at the isolation of compounds and opening the possibility of development of sophisticated pharmaceutical products (9). One of the salient examples is artepillin C, a component of B.dracunculifolia and green propolis with strong anti-bacterial and anti-tumor activities. The next step in this line of research seems to be the laboratorial synthesis of the substances, starting from abundant and low-cost raw material, thus making their use economically feasible in pharmacy and medicine.

A quick glance at the wide diversity of propolis composition revealed in the last 10-15 years foretells much further research work and a distant horizon for the completion of the evaluation of the full potentiality of propolis chemistry and pharmacology. Propolis research has uncovered pharmacological potentialities of substances previously known as plant constituents but never evaluated before. On the other hand, were it not for the labor of so many insects, each collecting minute portions of tissues and incorporating them into propolis, many valuable plant substances would hardly be uncovered.

\section{References}

1. Ghisalberti EL. Propolis—review. Bee World 1979;60:59-84.

2. Matsuno T. O efeito terapêutico da propolis. New York: Columbia University, Institute of Cancer Research, 1997 (in Portuguese).
3. Gabrys J, Konecki J, Krol W, Scheller S, Shani J. Free amino acids in bee hive product (propolis) as identified and quantified by gas-liquidchromatography. Pharmacol Res Comm 1986;18:513-8.

4. Marcucci MC, deCamargo FA, Lopes CMA. Identification of amino acids in Brazilian propolis. Zeitschrift Naturforschung C J Biosci 1996; $51: 11-4$.

5. Marcucci MC. Propolis-chemical-composition, biological properties and therapeutic activity. Apidologie 1995;26:83-99.

6. Bankova VS, de Castro SL, Marcucci MC. Propolis: recent advances in chemistry and plant origin. Apidologie 2000;31:3-15.

7. Banskota AH, Tezuka Y, Prasain JK, Matsushige K, Saiki J, Kadota S. Chemical constituents of Brazilian propolis and their cytotoxic activities. J Nat Prod 1998;61:896-900.

8. Lavie P. Les substances antibactériennes dans la colonie d'abeilles (Apis mellifica L.). Ann Abeille 1960;3:103-83 (in French).

9. Banskota AH, Tezuka Y, Kadota S. Recent progress in pharmacological research of propolis. Phytother Res 2001;15:561-71.

10. Kujumgiev A, Tsvetkova I, Serkedjieva Y, Bankova V, Christov R, Popov S. Antibacterial, antifungal and antiviral activity of propolis of different geographic origin. J Ethnopharmacol 1999;64:235-40.

11. Villanueva VR, Bogdanovsky D, Barbier M, Gonnet M, Lavie P. Sur l'identification de la 3,5,5-trihydroxy flavone (galangine) à partir de la propolis. Ann l'Institut Pasteur 1964;106:292-302 (in French).

12. Maciejewicz W, Daniewski M, Bal K, Markowski W. GC-MS identification of the flavonoid aglycones isolated from propolis. Chromatographia 2001;53:343-6.

13. Tomas-Barberán FA, Garcia-Viguera C, Vitolivier P, Ferreres F, TomásLorente F. Phytochemical evidence for the botanical origin of tropical propolis from Venezuela. Phytochemistry 1993;34:191-6.

14. Cuesta-Rubio O, Frontana-Uribe BA, Ramirez-Apan T, Cardenas J. Polyisoprenylated benzophenones in Cuban propolis; biological activity of nemorosone. Zeitschrift Naturforschung C J Biosci 2002; 57:372-8.

15. Sheppard WS, Rinderer TE, Mazzoli JA, Stelzer JA, Shimanuki H. Gene flow between African-derived and European-derived honey-bee populations in Argentina. Nature 1991;349:782-4.

16. Lobo JA, Del Lama MA, Mestriner MA. Population differentiation and racial admixture in the africanized honeybee (Apis mellifera L.). Evolution 1989;43:794-802.

17. Custodio AR, Ferreira MMC, Negri G, Salatino A. Clustering of comb and propolis waxes based on the distribution of aliphatic constituents. J Brazilian Chem Soc 2003;3:354-7.

18. Lopes FC, Bankova V, Sforcin JM. Effect of three vegetal sources of propolis on macrophages activation. Phytomedicine 2003;10:343-343.

19. Santos FA, Bastos EMA, Maia ABRA, et al. Brazilian propolis: physicochemical properties, plant origin and antibacterial activity on periodontopathogens. Phytother Res 2003;17:285-9.

20. Park YK, Paredes-Guzman JF, Aguiar CL, Alencar SM, Fujiwara FY. Chemical constituents in Baccharis dracunculifolia as the main botanical origin of southeastern Brazilian propolis. J Agric Food Chem 2004; $52: 1100-3$.

21. Espírito-Santo MM, Fernandes GW. Abundance of Neopelma baccharidis (Homoptera: Psyllidae) galls on the dioecious shrub Baccharis dracunculifolia (Asteraceae). Environmental Entomol 1998;27:870-6.

22. Kumazawa S, Yoneda M, Shibata I, Kanaeda J, Hamasaka T, Nakayama T. Direct evidence for the plant origin of Brazilian propolis by the observation of honeybee behavior and phytochemical analysis. Chem Pharm Bull 2003;51:740-2.

23. Park YK, Alencar SM, Aguiar CL. Botanical origin and chemical composition of Brazilian propolis. J Agric Food Chem 2002;50:2502-6.

24. Bankova V, Marcucci MC, Simova S, Nikolova N, Kujumgiev A, Popov S. Antibacterial diterpenic acids from Brazilian propolis. Zeitschrift Naturforschung C J Biosci 1996;51:277-80.

25. Banskota AH, Tezuka Y, Adnyana IK, et al. Hepatoprotective and antiHelicobacter pylori activities of constituents of Brazilian propolis. Phytomedicine 2001;8:16-23.

26. Ferracini VL, Paraiba LC. Essential oils of seven Brazilian species. J Essential Oil Res 1995;7:355-67.

27. Loayza I, Abujder D, Aranda R, et al. Essential oils of Baccharis salicifolia, B. latifolia and B. dracunculifolia. Phytochemistry 1995;38:381-9.

28. Weyerstahl P, Christiansen C, Marschall H. New sesquiterpene ethers and other constituents isolated from Brazilian 'vassoura oil'. Liebigs Annalen 1995;6:1039-43

29. Banskota AH, Tezuka Y, Adnyana IK, Midorikawa K, Matsushige K, Kadota S. Hepatoprotective and anti-Helicobacter pylori activities of constituents from Brazilian propolis. Phytomedicine 2001;8:16-23. 
30. Aga H, Shibuya T, Sugimoto T, Kurimoto M, Nakagima S. Isolation and identification of antimicrobial compounds in Brazilian propolis. Biosci Biotechnol Biochem 1994;58:945-6.

31. Matsuno T, Jung S-K, Matsumoto Y, Saito M, Morikawa J. Preferential cytotoxicity to tumor cells of 3,5-diprenyl-4-hydroxycinnamic acid (artepillin C) isolated from propolis. Anticancer Res 1997; 17:3565-8.

32. Negri G, Salatino MLF, Salatino A. 'Green propolis': unreported constituents and a novel compound from chloroform extracts. J Apicultural Res 2003; 42:39-41.

33. Simoes LMC, Gregorio LE, Da Silva AA, et al. Effect of Brazilian green propolis on the production of reactive oxygen species by stimulated neutrophils. J Ethnopharmacol 2004;94:59-65.

34. Banskota AH, Tezuka Y, Midorikawa K, Matsushige K, Kadota S. Two novel cytotoxic benzofuran derivatives from Brazilian propolis. J Natural Prod 2000;63:1277-9.

35. Hayacibara MF, Schobel BD, Cury JA, et al. Inhibition of Streptococcus mutans biofilm accumulation and polysaccharide production by apigenin and tt-farnesol. J Antimicrob Chemother 2003;52:782-9.

36. Matsuno T, Matsumoto Y, Saito M, Morikawa J. Isolation and characterization of cytotoxic diterpenoid isomers from propolis. Zeitschrift Naturforschung C J Biosci 1997;52:702-4.

37. Taniguchi M, Kataoka T, Suzuki H, et al. Costunolide and dehydrocostus lactone as inhibitors of killing function of cytotoxic T-lymphocytes. Biosci Biotechnol Biochem 1995;59:2064-7.
38. Negri G, Salatino MLF, Salatino A. Unusual chemical composition of a sample of Brazilian propolis, as assessed by analysis of a chloroform extract. J Apicultural Res 2003;42:53-6.

39. Marcucci MC, Rodriguez J, Ferreres F, Bankova V, Groto R, Popov S. Chemical composition of Brazilian propolis from São Paulo State. Zeitschrift für Naturforschung C J Biosci 1998;53:117-9.

40. Negri G, Marcucci MC, Salatino A, Salatino MLF. Comb and propolis waxes from Brazil: triterpenoids in propolis waxes. J Apicultural Res 2000;39:86-8.

41. Furukawa S, Takagi N, Ikeda T, et al. Two novel long-chain alkanoic acid esters of lupeol from alecrim-propolis. Chem Pharma Bull 2002;50: 439-40.

42. Sorkun K, Suer B, Salih B. Determination of chemical composition of Turkish propolis. Zeitschrift Naturforschung C J Biosci 2001;56: 666-8.

43. Bankova V, Popova M, Bogdanov S, Sabatini AG. Chemical composition of European propolis: expected and unexpected results. Zeitschrift Naturforschung C J Biosci 2002;57:530-3.

44. Cantrell CL, Nunez IS, Castaneda-Acosta, J, et al. Antimycobacterial activities of dehydrocostus lactone and its oxidation products. $J$ Natural Prod 1998;61:1181-6.

45. Woisky RG, Salatino A. Analysis of propolis: some parameters and procedures for chemical quality control. J Apicultural Res 1998;37: 99-105.

46. Bankova V, Marcucci MC. Standardization of propolis: present status and perspectives. Bee World 2000;81:182-8.

Received October 1 2004; accepted: January 102005 


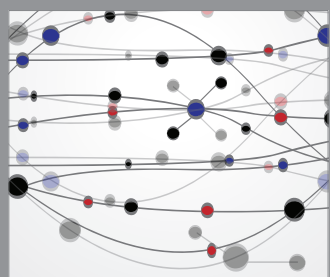

The Scientific World Journal
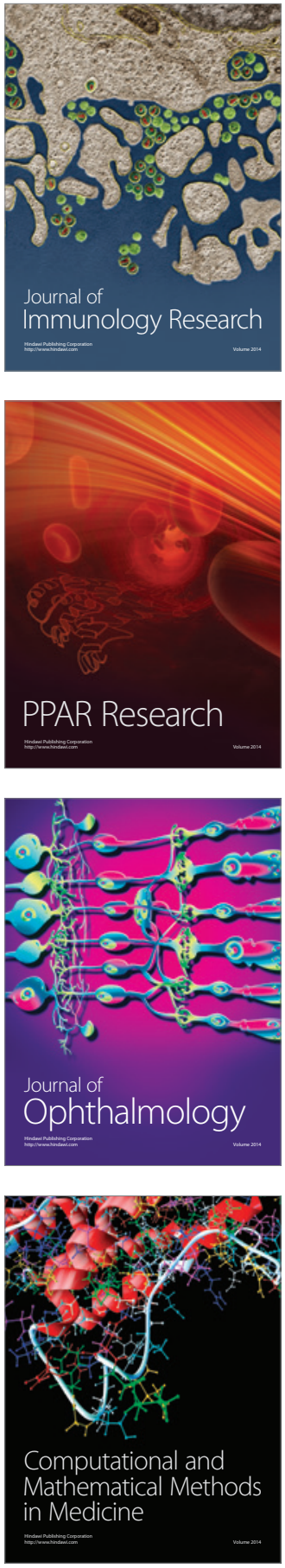

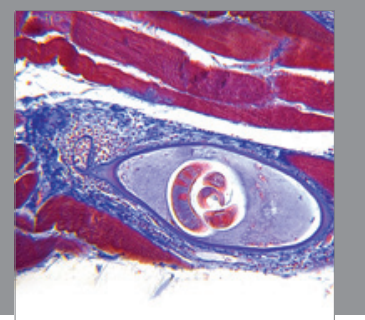

Gastroenterology

Research and Practice
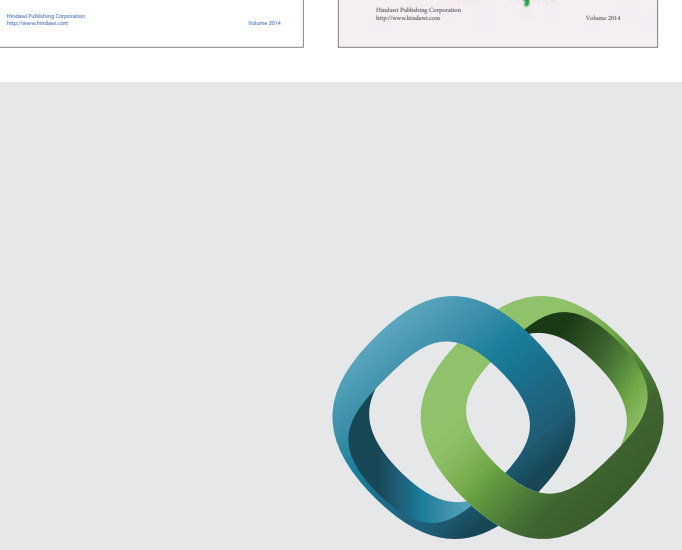

\section{Hindawi}

Submit your manuscripts at

http://www.hindawi.com
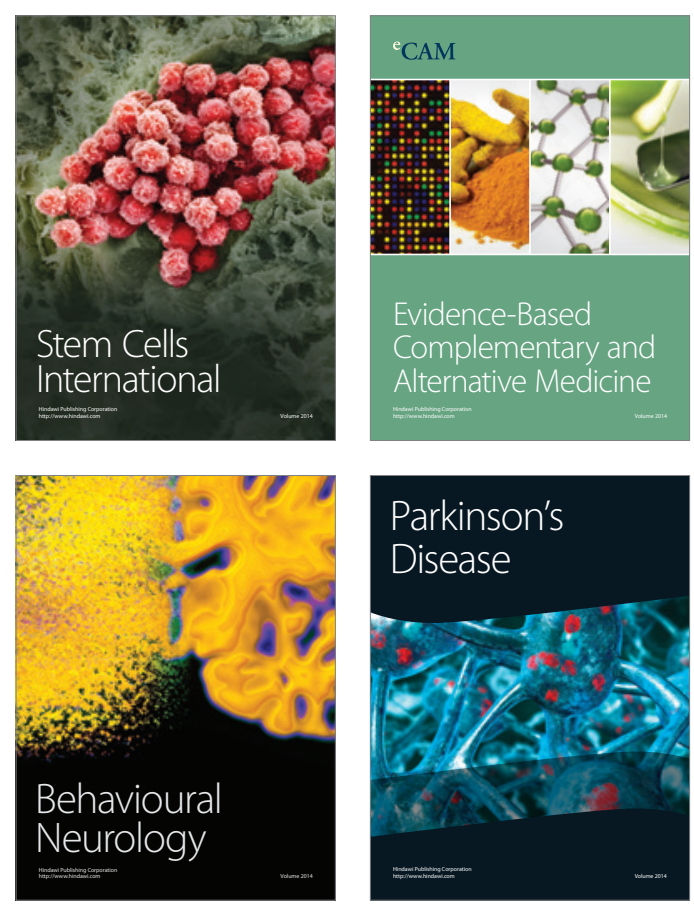

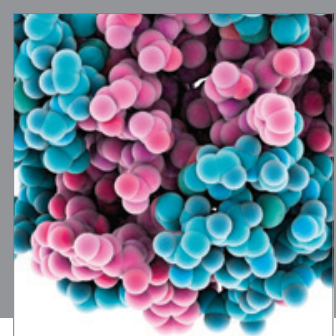

Journal of
Diabetes Research

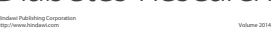

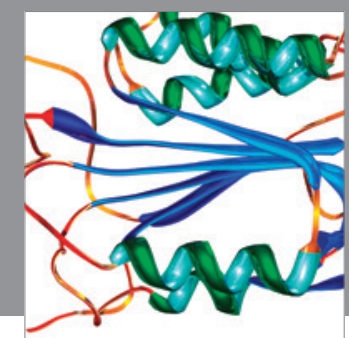

Disease Markers
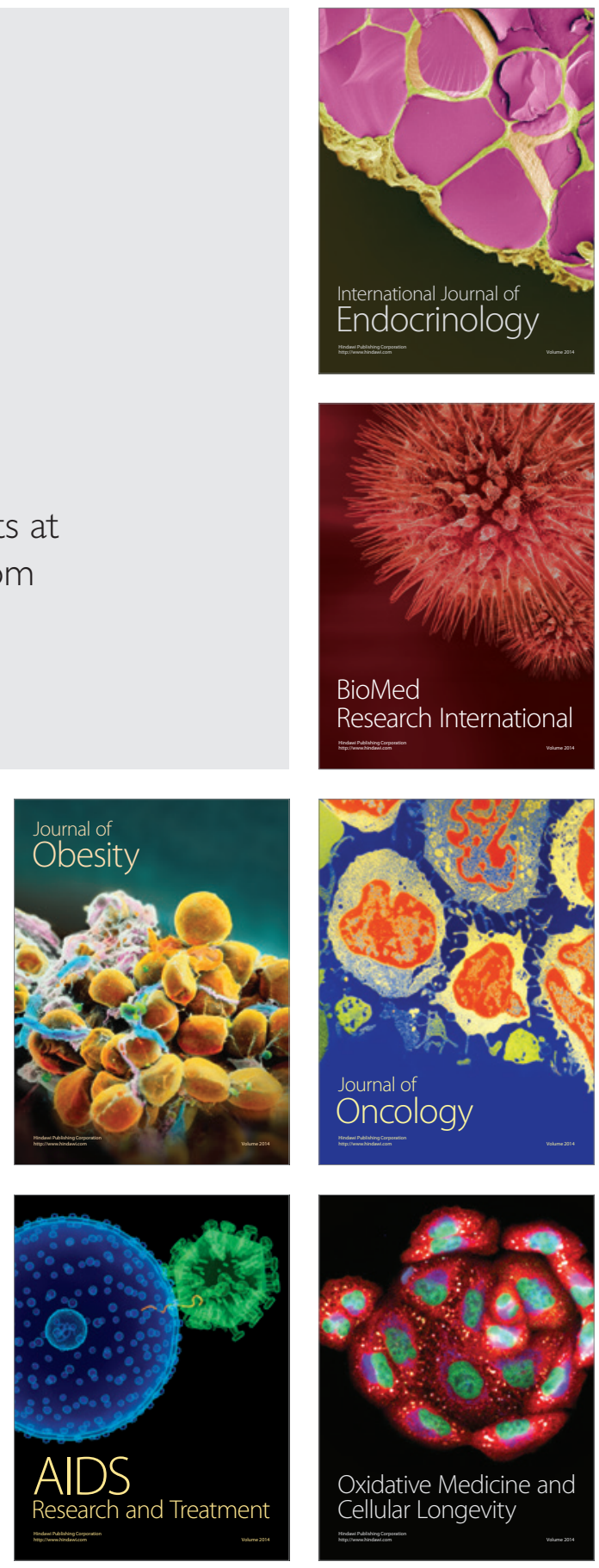